\title{
QUANDO O CRÍTICO SE RETIRA DA PLATEIA: A DESILUSÃO DE MACHADO DE ASSIS COM O TEATRO
}

\author{
Franceli Aparecida da Silva Mello \\ Universidade Federal de Mato Grosso \\ Cuiabá (MT), Brasil
}

\begin{abstract}
Resumo: A implantação de um teatro nacional de alto nível fez parte de um projeto político que a geração de Machado de Assis abraçou com entusiasmo, qual fosse o da modernização da sociedade com vistas à inserção do Brasil no "mundo civilizado". Neste artigo procuro demonstrar em que medida Machado de Assis engajou-se nesse projeto através de sua crítica teatral, bem como discutir as razões de seu afastamento do teatro a partir de um determinado momento de sua vida.
\end{abstract}

Palavras-chave: crítica teatral; modernização; teatro no Brasil; crônica.

When the critic withdraws from the audience: Machado de Assis's disillusionment with drama

\begin{abstract}
The creation of a high-level national theatre was part of a political project which the generation of Machado de Assis embraced with enthusiasm, that is to say, the modernization of society with a view to inserting Brazil in the "civilized world". In this essay, I try to demonstrate how much Machado de Assis engaged in this project through his theater reviews as well as discuss the reasons for his withdraw al from the theater at a certain moment of his life.
\end{abstract}

Keywords: theater reviews; modernization; theater in Brazil; chronicle. 
"O melhor drama está no espectador e não no palco."1

Em 1856, aos dezessete anos, Machado de Assis publicou uma série de três artigos sobre literatura no jornal A Marmota Fluminense, de Paula Brito. A despeito de sua fragilidade teórica, as "Ideias vagas" - assim ele denominou a série - são importantes por constituírem-se num primeiro esboço de reflexão crítica do autor.

No ensaio dedicado ao teatro, percebe-se claramente sua intenção de fazer propaganda da comédia moderna como meio de civilização. Para tanto, lança mão de formas de convencimento bastante incisivas, como se pode ver no enunciado que abre o texto:

O teatro, assim como a imprensa, é uma página brilhante pela qual se conhece o estudo e o grau de civilização de um povo. É isto uma verdade teórica conhecida por todos e que felizmente está ao salvo de quaisquer contestações, porque é inegável que a França, a sede das civilizações modernas, o foco luminoso da literatura e das ciências, mostra nas suas composições teatrais o esplêndido e alto grau de sua civilização e progresso intelectual. ${ }^{2}$

A implantação de um teatro nacional de alto nível fez parte de um projeto político que a geração de Machado de Assis abraçou com entusiasmo, qual seja, a modernização do país visando a sua inserção no "mundo civilizado".

Para José de Alencar, um dos mais ferrenhos defensores da causa, o maior obstáculo a vencer era a falta de patriotismo do público e da crítica. Ele mesmo se declara vítima disso em mais de uma ocasião. Em 1858, ao comentar a interdição da peça de sua autoria As asas de um anjo, afirma: "[...] tinha contra mim um grande defeito, e era ser a comédia produção de um autor brasileiro e sobre costumes nacionais [...]". ${ }^{3}$ Em 1875, atribuiu o fracasso de $O$ jesuíta "à indiferença desse público híbrido,

\footnotetext{
${ }^{1}$ ASSIS, Machado de. Obra completa. Rio de Janeiro: Editora Nova Aguilar, 1992. v. 2. p. 303.

${ }^{2}$ MASSA, Jean-Michel. Dispersos de Machado de Assis. Rio de Janeiro: MEC; INL, 1965. p. 31.

${ }^{3}$ ALENCAR, José de. Obra completa. Rio de Janeiro: Nova Aguilar, 1958. v. 3. p. 925.
} 
que desertou da representação de um drama nacional, inspirado no sentido patriótico, para afluir aos espetáculos estrangeiros."

De fato, o que prevalecia em nossos palcos eram as peças francesas originais ou traduzidas. As brasileiras, salvo raras exceções, eram cópias de modelos importados.

Em carta ao "redator em chefe" do Correio Mercantil, Alencar, empolgado, conclama seus colegas:

Nós todos jornalistas estamos obrigados a nos unir e criar o teatro nacional; criar pelo exemplo, pela lição, pela propaganda. É uma obra monumental que excede as forças do indivíduo e que só pode ser tentada por muitos, porém ligados pela confraternidade literária, fortes pela união, que é a força do espírito, como a adesão é a força do corpo. ${ }^{5}$

Não se sabe até que ponto por influência de Alencar, mas registra-se, a partir daí, um aumento nas produções nacionais, e a crítica teatral passa a ocupar mais espaço nos jornais.

Em seus primeiros escritos sobre teatro, Machado de Assis também irá demonstrar de forma ostensiva preocupações nacionalistas. No artigo "O passado, o presente e o futuro da literatura" (1858), delega ao teatro a responsabilidade pelo futuro da literatura brasileira. E, para incentivar a produção local, insurge-se contra as peças estrangeiras: "Para que estas traduções enervando a nossa cena dramática? Para que esta inundação de peças francesas, sem o mérito da localidade e cheias de equívoco, sensaborões às vezes, e galicismos, a fazer recuar o mais denodado francelho?". ${ }^{6}$

Machado atribui o atraso do nosso teatro ao abuso das traduções, responsáveis pela transformação da arte em indústria. Como solução para o problema, propõe medidas protecionistas - através de legislação que garantisse os direitos autorais aos escritores brasileiros e taxasse a importação/tradução de textos estrangeiros - e a adoção dos princípios da escola realista.

\footnotetext{
${ }^{4}$ ALENCAR, José de. Teatro completo. Rio de Janeiro: SNT, 1977. p. 263.

${ }^{5}$ ALENCAR, José de. Obra completa, cit., v.1. p. 40.

${ }^{6}$ ASSIS, Machado de. Obra completa, cit., v. 3. p. 788.
} 
Num primeiro momento parece incoerente que um jornalista engajado na luta pela criação do teatro nacional estivesse propugnando pela implantação de uma escola de matriz francesa. Mas, se considerarmos o caráter pragmático dessa escola, isto é, que ela se pautava pela discussão dos problemas sociais com a finalidade de instituir imprimir uma nova mentalidade, veremos que, naquele momento, a prioridade não era o desenvolvimento de uma estética original brasileira, mas fazer do teatro o veículo da mudança de que o país tanto necessitava. Contudo, a imitação da fórmula francesa deveria restringir-se ao nível da forma; o conteúdo seria resultante de observações do cotidiano da sociedade brasileira. Pensando nisso é que Machado de Assis cobra engajamento do literato nos movimentos sociais, pois acredita piamente no conceito hugoano de que o talento deve guiar a massa no sentido do progresso social e artístico.

\title{
A escola realista e a decadência do gosto
}

O modelo admirado pelo jovem cronista, entretanto, já vinha sendo questionado em sua matriz. Arnold Hauser, ao analisar a arte do Segundo Império francês, chama a atenção para o ecletismo característico do período, cuja principal consequência teria sido a sua total depreciação das artes. Autores como Octave Feuillet e Paul Baudry ocupavam mais espaço na consciência do público do que Flaubert ou Coubert. Segundo o historiador,

\begin{abstract}
A hipocrisia da burguesia é acompanhada de uma decadência sem precedentes no nível geral da cultura. [...] A arte como forma de desanuviamento, em que o público, consciente e deliberadamente, coloca-se abaixo do seu próprio nível é invenção do período; domina todas as formas de produção, mas principalmente, aquela que é, mais decididamente e sem escrúpulos, uma arte pública: o teatro.
\end{abstract}

No século XIX, os processos industriais e tecnológicos fizeram com que a produção artística se tornasse acessível a um número cada vez maior de pessoas. A imprensa viria substituir a influência da Igreja sobre as populações urbanas, tornando-se um poderoso formador de opinião. O teatro foi uma das formas de arte que mais

\footnotetext{
${ }^{7}$ HAUSER, Arnold. História social da literatura e da arte. 3. ed. Tradução Walter H. Geenen. São Paulo: Mestre Jou, 1982. p. 970.
} 
sofreram o fenômeno da massificação da cultura e dele se beneficiaram, pois, se por um lado houve um crescimento espantoso da atividade teatral, por outro a crítica opunha sérias restrições à qualidade das peças.

Se no Brasil o teatro realista surgia como uma solução para combater os exageros românticos, para muitos intelectuais europeus, a despeito de suas pretensões moralizantes, ele não passava de uma distração fácil, sem obscuridades, problemas insolúveis, profundezas insondáveis. Os dramaturgos, sob a alegação de tratarem das grandes questões sociais, não faziam mais que ratificar os princípios econômicos, sociais e morais da burguesia. Foi assim, segundo Hauser, que Scribe promoveu a reviravolta decisiva na história do drama francês. Ele deu uma expressão dramática à ideologia burguesa da Restauração e criou, com sua peça de intrigas, o instrumento mais bem calculado para servi-la. Dumas e Augier representam, no entender de Hauser, apenas uma forma mais evoluída do bon sens de Scribe, pois ambos proclamam o mesmo racionalismo e utilitarismo superficial, o mesmo otimismo e materialismo, "[...] a única diferença é que Scribe é mais honesto do que eles, e falava sem falsa modéstia e sem afetação acerca de dinheiro, de boas carreiras e de casamentos de conveniência, onde aqueles falam de ideias, de deveres e de amor eterno".

A multiplicidade de estilos gerou uma série de questionamentos, tanto da parte do artista como da crítica.

Ainda que nas grandes metrópoles houvesse público para abrigar todas as tendências, na medida em que crescia a frequência da massa aos teatros, muitos empresários passaram a dar preferência às montagens com maior apelo popular. $\mathrm{O}$ artista via-se diante do dilema de optar pela aquiescência da Academia e da crítica especializada, ou pelo sucesso junto ao público novo, a quem desejava atingir de qualquer maneira, quer entretendo-o, quer doutrinando-o segundo o código de valores burgueses. Os críticos progressistas também se viam numa situação bastante incômoda, pois a "degeneração do gosto", que então se observava, contrariava suas convicções quanto à capacidade das massas de apreciar as manifestações artísticas de alto nível.

A grande controvérsia drama do período residia na incompatibilidade entre os critérios de julgamento dos intelectuais e os das classes populares. Sarcey era um dos

\footnotetext{
${ }^{8}$ Idem, p. 971-972.
} 
poucos críticos cujas opiniões aproximavam-se das do grande público. Deste modo, a investigação sobre as causas da decadência do gosto do público passou a integrar as preocupações dos maiores críticos teatrais da época, como se pode observar nos comentários dos articulistas da Revue des Deux Mondes. Esta revista, juntamente com a Academia Francesa, detinha poder de consagração oficial, mas sua concepção de arte divergia radicalmente daquela do grande público.

Gustave Planche, crítico bastante conhecido e respeitado no Brasil, ${ }^{9}$ costumava responsabilizar artistas e empresários pela degeneração do gosto do público. Em 1856, escreve:

Ce qu'il y a de plus fâcheux dans l'etat présent de la littérature dramatique, c'est que le public ne prend pas le théâtre au sérieux. [...] $C^{\prime} e s t$ un fait malheureusement avéré, que nous devons constater: tant que la production dramatique sera ce qu'elle est aujourd'hui, nous ne pouvons guère espérer que le goût public s'élève ou s'épure. ${ }^{10}$

Em 1859, Eugène Lataye, após tecer comentários sobre as duas tendências que dividiam a arte dramática naquele momento - romantismo e realismo -, e sem tomar partido, conclui que a decadência se deve ao mau direcionamento dos objetivos do teatro. Na sua opinião, a arte deveria preocupar-se com a verdade e a beleza; corrigir os costumes ou divertir seriam objetivos secundários.

No mesmo ano, Émile Montégut atribui ao realismo a responsabilidade pela crise: "Je sais bien que le système du réalisme dramatique a um mérite incontestable, et que je me permettrai certaiment pas de contester: celui de dispenser l'auteur d'imagination, d'invention et de pensée". ${ }^{11}$

\footnotetext{
${ }^{9}$ Machado de Assis refere-se a ele como o mais ilustre crítico da escola clássica. (Diário do Rio de Janeiro, 03/10/1865).

${ }^{10}$ PLANCHE, Gustave. Revue des Deux Mondes, n.6, XXV. année, 2. periode, novembre, 1856. p. 700701. "O que há de mais deplorável no estado atual da literatura dramática, é que o público não leva o teatro a sério [...] É um fato infelizmente provado, que devemos constatar: enquanto a produção dramática for o que é hoje, não podemos esperar que o gosto do público se eleve ou se apure." (Tradução da autora).
}

${ }^{11}$ MONTÉGUT, Émile. Revue des Deux Mondes. XXIX année, 2. periode, novembre, 1859. p. 970. "Eu sei bem que o sistema do realismo dramático tem um mérito incontestável, e que certamente não me permitirei contestar: aquele de dispensar o autor de imaginação, de invenção e de pensamento." (Tradução da autora). 
Em 1861, o cronista da Revue des Deux Mondes registra a completa indigência do teatro francês e atribui ao conservadorismo do público parte da culpa por isso. Sendo avesso a mudanças, o público não prestigia o novo. Ao contrário, a reprise de uma peça antiga renderia mais do que uma estreia, e os empresários se aproveitariam disso para ganhar dinheiro, seu único interesse, segundo o revoltado cronista. Saudosista, Montégut refere o tempo em que o teatro ocupava lugar de destaque na vida intelectual francesa, não havendo ainda se transformado num prazer banal, um lugar onde se entrava como num café para ler um jornal. Para ele, só havia uma coisa que poderia disputar com as reprises a atenção do público de teatro: as apresentações de belas atrizes e dançarinas. Assim, a situação do teatro não era uma questão de arte, nem de literatura, "C'est un des ces faits accomplis que l'on constate, mais que l'on ne discute plus, un des ses faits qui sont intéressans pour l'histoire des moeurs, mais qui échappent à la competence de la critique littéraire". ${ }^{12}$

Montégut vê o ecletismo no teatro francês como um prejuízo para a arte. $\mathrm{Na}$ opinião dele, Sardou não se propôs a revolucionar na arte dramática, mas a ser divertido e, juntamente com Feuillet e Augier, promover uma obra de pacificação entre os gêneros, pois em suas composições podem-se encontrar elementos românticos, da escola do bom senso e realistas. Segundo Montégut, o teatro mudou porque a atmosfera moral e literária sofreu uma grande transformação no século XIX; já não se colocavam em cena os grandes problemas existenciais da humanidade, mas os circunstanciais $\mathrm{O}$ permanente fora substituído pelo descartável. Estes seriam os sinais dos tempos em que o progresso científico chegara aos espetáculos - crescia a importância do maquinista e do decorador. Em crônica do mesmo ano, o crítico observa:

Le théâtre existe donc, il prospère, il grandit même, et loin d'être en décadence, il n'a pas encore atteint son zénith. Il est riche de ressourses, d'inventions, de pratiques ingénieuses, d'artifices habiles. [...] Malheureusement la littérature dramatique est loin de partager cette fortune florisante; plus le théâtre grandit, plus elle décline. ${ }^{13}$

\footnotetext{
${ }^{12}$ Idem, XXXI. année, 2. periode, nov., 1861. p. 252. "É um desses fatos realizados que se constata, mas que não se discute mais, um desses fatos que são interessantes para a história dos costumes, mas que escapam à competência da crítica literária" (Tradução da autora).

${ }^{13}$ Idem, p. 749. "O teatro existe portanto, ele prospera, ele cresce mesmo, e longe de estar em decadência, ele ainda não atingiu o seu zênite. É rico de recursos, de invenções, de práticas engenhosas, de artifícios
} 
Numa análise menos apaixonada, Armand de Pontmartin também lamenta a decadência da arte contemporânea, mas aconselha os críticos a não serem pessimistas; humilhar o artista não era uma boa política. O cronista também relaciona a transformação do teatro às novas condições vigentes na sociedade francesa, assim relacionando também a queda da barreira inflexível entre os gêneros artísticos à queda do Antigo Regime. Para ele, o teatro, como a sociedade, democratizara-se; entretanto, se a nova situação política trouxera ganhos sociais, o mesmo não acontecera com a arte. No teatro o nivelamento se fez por baixo: a tragédia decompôs-se em melodrama, a comédia entremeou-se de vulgaridades, de negligências, de improvisação e de incorreções de forma.

Numa comparação entre Scribe e Sardou, o crítico atribui ao primeiro um espírito francês, parisiense, e, ao outro, uma fisionomia americana, afeita aos extremos. Scribe, por preferir o meio termo, procede de maneira mais temperada, como convém ao homem civilizado das sociedades modernas. Não é só Pontmartin quem critica Sardou; Prevost-Paradol não gosta dos heróis de suas peças: geralmente um tipo insuportável de engenheiro que chega trazendo o progresso e se casa com a filha de um aristocrata, unindo, ao final, o antigo e o moderno. Para o cronista, Sardou abusa do tipo - que não era exclusividade sua, mas lugar comum no teatro da época - para passar uma lição política, qual seja, "é preciso ser um homem de seu tempo".

Saint-René Taillandier reitera a opinião de seus pares quanto à decadência da sensibilidade do público, mas introduz um elemento novo entre os critérios de avaliação. Ao comentar Le Supplice d'une femme, de E. Girardin e Dumas Filho, atribui a beleza do espetáculo à boa montagem - até então, o costume era avaliar a montagem separadamente, atribuindo-lhe um peso menor em relação ao texto:

La violance et la fausseté de la conception pèsent sur l'ouvrage tout entier. [...] je dirai même que l'agilité matérielle de la mise en scène était ici une condition indispensable; quelques minutes d'entre acte, pas davantage: il ne fallait pas que le spectateur eût le temps de respirer. Quelle que soit pourtant l'habilité de l'escamotage et malgré

hábeis. [...] Infelizmente a literatura dramática está longe de compartilhar esta riqueza florescente; mais o teatro cresce, mais ela declina." (Tradução da autora). 
tout le talent des acteurs, est-il d'une grande sagacité pour decouvrir le défaut de la cuirasse. ${ }^{14}$

O estágio avançado do teatro francês permitia à crítica o luxo de assumir uma atitude blasé tanto diante do velho, quanto diante das novidades que surgiam na cena. Entre nós, contudo, o quadro era bem outro. A Revue des Deux Mondes tinha no Brasil o maior número de assinantes fora da França, ${ }^{15}$ portanto sua crítica teatral não era ignorada pelos nossos literatos. Porém, a necessidade de construção levava a atitudes mais condescendentes. $\mathrm{O}$ crítico brasileiro sentia-se no dever de incentivar tudo o que se caracterizasse como contribuição para o teatro nacional. Mas incentivo não significava aprovação; ao apontar os defeitos e aplaudir as qualidades, acreditava estar orientando os artistas no caminho da perfeição. Assim, a nossa crítica diferia essencialmente da praticada na Revue des Deux Mondes, principalmente pelo didatismo e engajamento num projeto político de modernização nacional.

Machado de Assis, também um leitor da Revue, não postulava integralmente o ideário crítico de seus colegas franceses. Se em alguns casos suas opiniões coincidiam, em outros o brasileiro demonstrava uma autonomia surpreendente, tratando-se de um jovem de país periférico. Considerava Montégut muito severo para com seus contemporâneos e não desaprovava o ecletismo de Sardou e Augier; ao contrário, em seus pareceres para o Conservatório Dramático comparou o primeiro a Molière e elogiou muito as peças Os descarados e As leoas pobres, de Augier. Acompanhou a polêmica provocada na França em torno de Le Supplice d'une femme - cuja tradução para o português é de sua autoria -, manifestando-se favoravelmente aos autores em sua coluna no Diário de Rio de Janeiro, em 1865.

Não obstante acompanhasse de perto o movimento dramático na França, Machado tinha consciência da distância que nos separava daquele que era então considerado o centro da arte e da civilização. Mas num ponto parecia estar em total

\footnotetext{
${ }^{14}$ TAILLANDIER, Saint-René. Revue des Deux Mondes. XXXV année, 2. periode, nov., 1865. p. 525. "A violência e a falsidade da concepção pesam sobre toda a obra. [...] direi mesmo que a agilidade material da mise en scène foi aqui uma condição indispensável; alguns minutos de entreato, não mais: não era necessário que o espectador tivesse tempo de respirar. Qualquer que seja, portanto, a habilidade do encobrimento e apesar de todo o talento dos atores, é de uma grande sagacidade para descobrir o ponto fraco." (Tradução da autora).

${ }^{15}$ Cf. SODRÉ, Nelson Werneck. História da imprensa no Brasil. Rio de Janeiro: Civilização Brasileira, 1966. (Coleção Retratos do Brasil).
} 
concordância com os críticos franceses: havia que se combater a decadência do gosto. É com esta convicção que Machado assumiria seu papel na crônica de jornal, onde não se dirigia apenas a literatos, artistas e empresários, mas a um público heterogêneo, cuja maior parte precisava ser iniciada na prática da apreciação artística. Assim, a postura do crítico não seria apenas de cobrança; tomava para si a tarefa de educar o gosto do público, a fim de dar-lhe condições de separar o joio do trigo.

\section{A desilusão}

Tarefa inglória! Em 1862, Machado de Assis publica um artigo no Diário do Rio de Janeiro em que expressa seu desgosto com os rumos que a política vinha tomando no país. Alguns anos depois, nota-se o arrefecimento do seu entusiasmo pelo teatro. No artigo que abre a série "O teatro nacional", ${ }^{16}$ de 1866, o crítico declara seu pessimismo em relação ao futuro do teatro brasileiro, constatando entre nós os mesmos problemas apontados pelos críticos franceses em seu contexto, referidos acima. Para Machado, o público passa a frequentar as salas de espetáculo apenas para "desenfastiar o espírito, nos dias de maior aborrecimento", e as reformas romântica e realista, ao transformarem tais estilos em ultrarromantismo e ultrarrealismo, deterioraram a arte Exagerando os preceitos das escolas, apresentavam-se composições monstruosas, informes, sem arte e sem gosto, afirmava o crítico, que também responsabiliza governo pela crise. Ainda assim, ele não se demonstra totalmente desiludido e dá uma série de sugestões práticas e teóricas, acalentando a esperança numa reforma que restabeleça a "aliança entre o público e o poeta e faça renascer a já perdida noção de gosto". Mas esta peça crítica parece ter sido a última atitude militante de Machado de Assis em favor do teatro.

Muito se especula sobre as razões do afastamento de Machado do ambiente teatral. Resgata-se a influência que o casamento teve em sua vida, transformando-lhe os hábitos. As noites seriam reservadas para as conversas com Carolina, ou para visitas aos amigos; não mais para palestras nos jardins dos teatros. ${ }^{17}$

\footnotetext{
${ }^{16}$ ASSIS, Machado de. Obra completa, cit., v. 3. p. 861-866.

17 CUNHA, Ciro Vieira da. O teatro de Machado de Assis. Jornal do Commercio, Rio de Janeiro, 26/07/1942.
} 
Naquele tempo, o Rio de Janeiro oferecia outras opções de divertimentos a fazerem concorrência ao teatro. As companhias de prodígios e as touradas eram frequentemente mencionadas por Machado como exemplos da decadência do ambiente cultural. Esse contexto desfavorável à apreciação estética e a falta de reconhecimento ao seu empenho em orientar os talentos também devem ter pesado na sua decisão de abandonar a militância na crítica teatral.

Mais de um autor refere-se ao temperamento polido, escrupuloso e susceptível de Machado como um fator responsável pela sua desistência do ofício de crítico. Segundo Mário de Alencar, ${ }^{18}$ o receio de magoar, embora dizendo a verdade, pode tê-lo feito dissuadir-se dessa atividade. Astrojildo Pereira afirma:

[...] a crítica, se era uma vocação do seu espírito, não se ajustaria convenientemente ao seu temperamento, sobretudo num meio como o nosso e num período histórico que reclamava antes de mais nada combatividade, polêmica, demolição. Demais disso, a sua vocação crítica - para insistirmos em lhe fixar essa característica - seria mais propriamente uma vocação de outra natureza, que só poderia exercerse em toda a sua plenitude como crítica geral da sociedade, sob a forma de criação artística. ${ }^{19}$

Mário de Alencar e Lúcia Miguel Pereira comungam deste ponto de vista. Para a última, na medida em que Machado foi ganhando estabilidade em vários aspectos de sua vida, foi perdendo todas as crenças, e só quando chegou à descrença total é que produziu suas grandes obras. Se tomarmos tais assertivas como verdadeiras, teremos uma ideia do quanto ia ficando difícil para o crítico emitir juízos de valor nos moldes da crônica de folhetim. Em 1879 ele já não acreditava no potencial revolucionário da arte. Classifica como ingenuidade a crença de Garrett na influência social da literatura, afirmando: "Garrett, ingênuo às vezes, como um grande poeta que era, atribui aos versos uma porção de grandes coisas sociais que eles não fizeram, os pobres versos $[\ldots] " .20$

\footnotetext{
${ }^{18}$ ALENCAR, Mário. Alguns escritos. Rio de Janeiro: Garnier, 1910.

${ }^{19}$ PEREIRA, Astrogildo. Machado de Assis. Rio de Janeiro: São José, 1959. p. 109.

${ }^{20}$ ASSIS, Machado de. Obra completa, cit., v. 3. p. 812.
} 
Outro fator a ser considerado, quando se investigam as causas do desânimo de Machado com o teatro, é a sua frustração por não ter conseguido, enquanto crítico, formar a opinião do público a favor do teatro realista. As personagens frequentadoras de teatro que aparecem nos seus contos podem ser tomadas como exemplo do público da época. Se havia as Marocas, as Cecílias e Marcelinas, que morriam pelo teatro, para usar uma expressão do tempo, havia outras para quem ele tinha pouca, ou nenhuma, importância. Para ele, não deveria ser fácil constatar que o público das peças realistas provavelmente muitas das "belas leitoras" de suas revistas dramáticas - não fora suficientemente convencido a rechaçar o gênero alegre, quando este começou a predominar em nossos palcos. Pelo contrário, a "boa sociedade" afluía a esses espetáculos com igual ou maior entusiasmo.

Não era apenas Machado de Assis quem mudava; o teatro brasileiro também já não era o mesmo. Apenas a sua situação de precariedade permanecia inalterada. João Caetano morrera pobre em 1863; dez anos depois, em 26/01/1873, nas condolências pela morte do ator Joaquim Augusto Ribeiro de Souza, A Semana Ilustrada enfatiza ter sido o artista "vítima de moléstia agravada pela pobreza". Outros jornais insinuavam que os maiores motivos de suicídios entre os atores eram o desemprego e os baixos salários.

José de Alencar, Quintino Bocaiuva e tantos outros já vinham denunciando a ameaça do chamado "gênero alegre" ao teatro de tese, desde a chegada daquele ao Brasil, no final dos anos de 1850. Machado de Assis, em seu hoje célebre ensaio "Notícia da atual literatura brasileira - instinto de nacionalidade" (1873), constatava amargamente:

Não há atualmente teatro brasileiro, nenhuma peça nacional se escreve, raríssima peça nacional se representa. [...] Hoje, que o gosto do público tocou o último grau de decadência e perversão, nenhuma esperança teria quem se sentisse com vocação para compor obras severas de arte. Quem lhas receberia, se o que domina é a cantiga burlesca ou obscena, o cancã, a mágica aparatosa, tudo o que fala aos sentidos e aos instintos inferiores? ? $^{21}$

\footnotetext{
${ }^{21}$ Idem, p. 808.
} 
Com esta afirmação Machado não fazia mais do que sintetizar uma opinião quase unânime entre os críticos teatrais da época. Joaquim Nabuco, recém-chegado ao Brasil, no artigo em que desencadeou a polêmica com Alencar em 1875, reproduz a voz corrente entre os jornalistas, ou seja: "O teatro deixou de ser escola de costumes e de língua, a estética desertou dali e a imprensa emudeceu". ${ }^{22}$ De sua parte, Alencar desfere um ataque direto ao espetáculo aparatoso:

O teatro não é uma iluminação, uma fantasmagoria, ou uma destas festas venezianas de fogos de artifício e surpresas deslumbrantes. Aí os principais espectadores são o espírito e o coração; e não os olhos e os ouvidos.

É, sobretudo, esta falsa escola que gradua o drama pelo rumor, pelo painel, pelos efeitos de ótica, que a imprensa ilustrada deve porfiar em combater, para educar o público. ${ }^{23}$

Ao saudar, em 1873, a reinauguração do Alcazar com a opereta Les brigands, de Offenbach, o cronista da Semana Ilustrada reconhece um de seus méritos. Para o colunista da seção "Teatrices", a reabertura do teatro teria devolvido a alegria à cidade. Despretensiosamente, ele desvendava para os leitores brasileiros a função social do gênero que estava dominando os palcos do mundo inteiro.

Segundo Arnold Hauser, como produto artístico do Segundo Império, a opereta tinha como uma de suas funções transmitir àquela época tão grave e insípida alguma coisa do espírito leve, alegre, não romântico do século XVIII. Para o autor, o caráter estereotipado dos seus conteúdos, o convencionalismo dos seus enredos e desenlaces eram puras formas teatrais sem relação com a realidade. A opereta era não só uma imagem da sociedade frívola e cínica daquele tempo, mas uma forma de autocrítica ridicularizante; era o produto de um liberalismo econômico, social e moral em que tudo era permitido, menos discutir o sistema em si. O governo tolerava a sátira social da opereta, porque se dirigia a um público cuja lealdade não admitia dúvidas e que não precisava de outra válvula de escape além da encenação desta coluna de boatos a propósito dos escândalos da sociedade elegante.

\footnotetext{
${ }^{22}$ COUTINHO, Afrânio (Org.). Polêmica Alencar-Nabuco. Rio de Janeiro: Tempo Brasileiro, 1965. p. 16.

${ }^{23}$ Idem, p. 39.
} 
No Brasil, onde o sistema político estava sendo questionado, a possibilidade da Abolição assustava alguns setores da economia e a instabilidade financeira fazia fortunas e promovia derrocadas da noite para o dia, a ascensão da opereta veio em boa hora. Além de desanuviar a vida da população, tirou algumas empresas teatrais de sérias dificuldades financeiras. Artur Azevedo foi um dos que se beneficiaram disso. $\mathrm{Na}$ carta-resposta em que se defende da pecha de ter provocado a débacle teatral no Brasil, ele escreve:

[...] todas as vezes que tentei fazer teatro sério, em paga só recebi censuras, apodos, injustiças e tudo isso a seco; ao passo que, enveredando pela bambochata, não me faltaram nunca elogios, festas, aplausos e proventos. Relevem-me citar esta última fórmula de glória, mas - que diabo! - ela é essencial para um pai de família que vive de sua pena!.... ${ }^{24}$

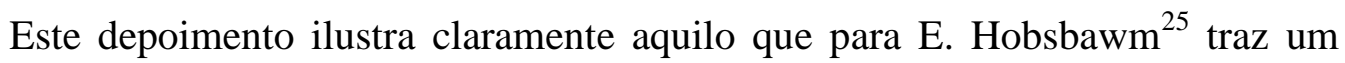
significado frequentemente subestimado quando se estuda a economia do século XIX, ou seja, o mercado de massas relacionado à arte.

Outro gênero patrocinado pelos deslumbramentos das visualidades e riqueza dos acessórios era a mágica. Artur Azevedo, comentando o trabalho do cenógrafo Gaetano Carrancini, registra a sofisticação dos efeitos especiais criados por ele num espetáculo desse gênero: "o cenário é sempre maquinado e o cenógrafo reclama a colaboração subalterna do carpinteiro; há flores que se transformam em estrelas, colunas que giram, águas que jorram, grupos maravilhosamente combinados, harmonia de cores, efeitos de projeções luminosas, etc." 26

A Machado de Assis desagradava sobremaneira esse tipo de espetáculo, principalmente quando era resultado de adaptações de outras formas literárias. No prefácio às Mil e uma noites, de Carlos Jansen (1882), escreve:

\footnotetext{
${ }^{24}$ AZEVEDO, Artur. O País. Rio de Janeiro, 16/05/1904.

${ }^{25}$ HOBSBAWM, Eric J. A era do capital (1848-1875). 3. ed. Tradução Luciano Costa Neto. Rio de Janeiro: Paz e Terra, 1982.

${ }^{26}$ Citado em: PRADO, Décio de Almeida. Seres, coisas, lugares: do teatro ao futebol. São Paulo: Companhia das Letras, 1997. p. 27.
} 


\begin{abstract}
Algumas dessas figuras andam até vulgarizadas em peças mágicas de teatro, pois aconteceu às Mil e uma Noites o que se deu com muitas outras invenções: foram exploradas e saqueadas para a cena. [...] Nem Shakespeare escapou, o divino Shakespeare, como se Macbeth precisasse do comentário de nenhuma outra arte, ou fosse empresa fácil traduzir musicalmente a alma de Hamlet. ${ }^{27}$
\end{abstract}

O fato é que, ao aderirem ao gênero musicado, as companhias teatrais brasileiras pretendiam enfrentar a concorrência das estrangeiras, que nas férias de verão afluíam aos palcos brasileiros, arrebatando-lhes o público.

A fórmula do sucesso também incluía o tratamento dado ao anúncio do espetáculo. Além do nome de autor, cenógrafo, atores e atrizes famosos, número de representações, o aparato cenográfico funcionava como chamariz.

A ascensão do gênero musicado significou o decréscimo das aspirações literárias no teatro. Para Décio de Almeida Prado, foi o anticlímax dos teatros romântico e realista. Não falava de liberdade e nacionalismo, como o primeiro; nem sobre a moral da família burguesa, como o segundo. Limitava-se à diversão pura e simples. Uma consequência disso, creio, foi que a crítica, da maneira como era a praticada por Machado de Assis e seus companheiros de geração, tornou-se inoperante.

Assim, na medida em que o teatro ia se apartando da literatura, os literatos se afastavam da militância teatral, deixando o espaço para ser ocupado por pessoas mais familiarizadas com a nova estética, os chamados "homens de teatro".

Não obstante o fracasso do teatro realista no Brasil, o discurso estabelecido pela crítica do período arraigou-se de tal forma entre os historiadores da nossa dramaturgia, que só mais recentemente desfez-se o preconceito estético contra o gênero teatral que o sucedeu. Provavelmente porque esse discurso se apoiasse na tradição aristotélica da valorização do literário em detrimento do espetacular. Cabe lembrar que o capítulo sobre as diferentes partes da tragédia (o de número VI da Arte poética) termina com a seguinte observação:

Dos restantes componentes é o canto o maior dos ornamentos. O espetáculo, embora fascinante, é o menos artístico e mais alheio à

\footnotetext{
${ }^{27}$ ASSIS, Machado de. Obra completa, cit., v.3. p. 918.
} 
poética; dum lado, o efeito da tragédia subsiste ainda sem representação nem atores; doutro, na encenação, tem mais importância a arte do contrarregra do que a dos poetas. ${ }^{28}$

Se, na condição de crítico teatral, Machado de Assis viu frustrado o projeto de implantação de um determinado modelo dramático - não formou a opinião, nem conseguiu a adesão da maioria dos autores brasileiros ao drama "sério" -, para o ficcionista o exercício dessa atividade trouxe muitos benefícios. Se, em algumas ocasiões, Machado referiu-se ao exercício da crítica como um sacrifício consagrado às letras nacionais, ele soube, em compensação, tirar proveito para si desse gesto de abnegação.

Nas crônicas teatrais, seu discurso transformou-se ao longo do tempo, refletindo-se, esta transformação, num estilo narrativo igualmente mutante. Some-se a isso a recorrência de imagens referentes à mutabilidade incessante da vida, dos seres, das ideias e teremos a origem, parece-me, da volubilidade do narrador machadiano, estudada por Roberto Schwarz. ${ }^{29}$ Mais de um autor assinalou o jogo de mascarada presente no discurso machadiano, sendo Raimundo Magalhães Júnior um dos primeiros a fazê-lo.

Segundo José Castello, ${ }^{30}$ a aparente acomodação de Machado de Assis às vezes era uma forma de autodefesa. A tolerância convertia-se em neutralização ou omissão de julgamento, e este era substituído pelo humor. Aqui teríamos mais uma das causas de sua desistência da crítica em favor da criação ficcional. Sobre a influência da crítica na prosa de ficção machadiana, Castello observa que através dela o autor dedicou-se à investigação do pensamento e do sentido humano e social da obra literária. Para Lúcia Miguel Pereira, a necessidade de observar, exigida pela crítica, foi a melhor educação intelectual para o jovem de rara penetração psicológica, mas de imaginação convencionalmente romântica.

\footnotetext{
${ }^{28}$ ARISTÓTELES. A poética clássica: Aristóteles, Horácio, Longino. Tradução do grego e do latim por Jaime Bruna. São Paulo: Cultrix; Edusp, 1981. p. 26.

${ }^{29}$ SCHWARZ, Roberto. Um mestre na periferia do capitalismo: Machado de Assis. São Paulo: Duas Cidades, 1990.

${ }^{30}$ CASTELLO, José Aderaldo. Realidade e ilusão em Machado de Assis. São Paulo: Companhia Editora Nacional; Edusp, 1969.
} 
Outro legado do crítico ao romancista foi, a meu ver, a adoção de uma atitude independente em relação às escolas, sem, no entanto, desprezar o melhor de cada uma delas. Ao exercer a crítica literária e teatral, Machado de Assis obrigatoriamente voltouse para os problemas relacionados ao gosto da época. Discutiu e reconheceu as heranças e os defeitos do Classicismo, do Romantismo e do Realismo e orientou os autores no combate ao lugar comum e aos exageros. Além disso, ao optar pelo ecletismo, colocouse acima das normas limitadoras que prejudicavam a criação, com resultados bastante satisfatórios.

Como se pode observar em relação à crítica dramática, com o passar do tempo, Machado de Assis vai progressivamente reduzindo sua preocupação política imediatista em favor de questões sociais e humanas mais abrangentes e do apuro formal; ainda aqui, teríamos a crítica a nortear-lhe os caminhos. Ela o teria levado a outra compreensão da arte, ou seja, da arte como produção desinteressada.

Em algumas de suas crônicas da maturidade veremos que a arte irá afigurar-selhe como o melhor lenitivo para a dor de viver. Em crônica de 1895, Machado afirma que, se quisesse fugir das agruras da vida, buscaria asilo num hospício ou na arte, sendo esta última, "De todas as coisas humanas [...] a única que tem o seu fim em si mesma...". ${ }^{31}$ Em 1885, no prefácio ao livro Miragens, dá como conselho ao poeta Eneias Galvão: "Crer nas musas é ainda uma das coisas melhores da vida". Dirigindose a Lúcio de Mendonça, em crônica de 1896, escreve: "Ei-nos aqui os dois, após tantos anos, sem haver descrido das letras, e achando nelas um pouco de descanso e um pouco de consolo". Na crítica ao livro Horas sagradas, de Magalhães de Azeredo, relativiza seu pessimismo, afirmando: "[...] se não somos dos que creem no fim do mal, não descremos da nobreza do esforço, e sobretudo das consolações da arte".

Machado de Assis não estava totalmente cético, ainda acreditava em alguma coisa, mas não era na crítica literária ou teatral. Assim como fez com a política, foi abandonando-as aos poucos e fechando-se na rotina da repartição e da produção ficcional, diminuindo, assim, as possibilidades de choque.

O teatro fazia parte de um tempo em que havia mais fervor, para usar de uma expressão sua em carta a Tomás da Porciúncula. Nela, Machado faz uma homenagem

\footnotetext{
${ }^{31}$ ASSIS, Machado de. Obra completa, cit., v.3. p. 678.
} 
póstuma a Fagundes Varela; falando sobre os anos de 1860, escreve: "Havia mais fervor naquele tempo, ou eu falo com as impressões de uma idade que passou? Parece-me que a primeira hipótese é a verdadeira. Vivia-se de imaginação e poesia; cada produção literária era um acontecimento". ${ }^{32}$

De fato, a juventude de então parecia demonstrar mais entusiasmo literário. Raimundo Magalhães Júnior conta-nos que por volta dos anos de 1858-60 havia um grupo juvenil que procurava dinamizar a vida literária do Rio de Janeiro, e dentre os jovens byronianos que se reuniam no escritório do advogado Caetano Filgueiras para falar de poesia estava Machado de Assis. Este, porém, não se preocupava com a morte, como seus companheiros Casimiro de Abreu e Gonçalves Braga. Enquanto eles produziam poesias fúnebres, Machado publicava no Correio Mercantil o poema "Esperança". ${ }^{33}$

Em 1858, era o Machadinho otimista que empenhava sua fé no futuro do teatro nacional, ao escrever: "É assim que o teatro nascerá é viverá; é assim que se há de construir um edifício de proporções tão colossais e de um futuro tão grandioso". No entanto, foi o Machado de Assis desiludido quem nos deu a maior contribuição para a literatura nacional.

Referências:

ALENCAR, José de. Obra completa. Rio de Janeiro: Nova Aguilar, 1958. v. 3.

ALENCAR, José de. Teatro completo. Rio de Janeiro: SNT, 1977.

ALENCAR, Mário. Alguns escritos. Rio de Janeiro: Garnier, 1910.

ARISTÓTELES. A poética clássica: Aristóteles, Horácio, Longino. Tradução do grego e do latim por Jaime Bruna. São Paulo: Cultrix; Edusp, 1981.

\footnotetext{
${ }^{32}$ Idem, p. 902.

${ }^{33}$ Cf. MAGALHÃES JÚNIOR, Raimundo. Quando Machado de Assis era otimista. Correio da Manhã. Rio de Janeiro, 04/01/1958.
} 
ASSIS, Machado de. Obra completa. Rio de Janeiro: Editora Nova Aguilar, 1992. v. 2 e 3 .

AZEVEDO, Artur. O País. Rio de Janeiro, 16/05/1904.

CASTELLO, José Aderaldo. Realidade e ilusão em Machado de Assis. São Paulo: Companhia Editora Nacional; Edusp, 1969.

COUTINHO, Afrânio (Org.). Polêmica Alencar-Nabuco. Rio de Janeiro: Tempo Brasileiro, 1965.

CUNHA, Ciro Vieira da. O teatro de Machado de Assis. Jornal do Commercio, Rio de Janeiro, 26/07/1942.

HAUSER, Arnold. História social da literatura e da arte. 3. ed. Tradução Walter H. Geenen. São Paulo: Mestre Jou, 1982.

HOBSBAWM, Eric J. A era do capital (1848-1875). 3. ed. Tradução Luciano Costa Neto. Rio de Janeiro: Paz e Terra, 1982.

MAGALHÃES JÚNIOR, Raimundo. Quando Machado de Assis era otimista. Correio da Manhã. Rio de Janeiro, 04/01/1958.

MASSA, Jean-Michel. Dispersos de Machado de Assis. Rio de Janeiro: MEC; INL, 1965.

MONTÉGUT, Émile. Revue des Deux Mondes. XXIX année, 2. periode, novembre, 1859.

PEREIRA, Astrogildo. Machado de Assis. Rio de Janeiro: São José, 1959.

PLANCHE, Gustave. Revue des Deux Mondes, n.6, XXV. année, 2. periode, novembre, 1856. p. 700-701.

PRADO, Décio de Almeida. Seres, coisas, lugares: do teatro ao futebol. São Paulo:

Companhia das Letras, 1997.

SCHWARZ, Roberto. Um mestre na periferia do capitalismo: Machado de Assis. São Paulo: Duas Cidades, 1990.

SODRÉ, Nelson Werneck. História da imprensa no Brasil. Rio de Janeiro: Civilização Brasileira, 1966.

TAILLANDIER, Saint-René. Revue des Deux Mondes. XXXV année, 2. periode, nov., 1865 .

Franceli Aparecida da Silva Mello, doutora em Literatura Brasileira pela Universidade de São Paulo e com pós-doutoramento pela Universidade Estadual de Campinas, é professora do Departamento de Letras e do Mestrado em Estudos da Linguagem da Universidade Federal de Mato Grosso. Entre suas produções mais recentes, estão: "Machado de Assis e o teatro: um caso de amor", em $O$ eixo e a roda: revista de 
literatura brasileira, v. 9/10 (Belo Horizonte: UFMG, 2003; 2004); e "Sorria, você está sendo filmado: uma leitura de 'Conto de escola', de Machado de Assis", em Investigações: Linguística e Teoria Literária, v. 21, n.1 (Recife: Ed. Universitária da UFPE, 2008). E-mail: <celismello@ hotmail.com>

Recebido: $13 / 09 / 2011$

Aprovado: 28/11/2011 